\title{
Commentary Antithrombin in sepsis revisited
} Marcel Levi

Chairman of Medicine, Department of Vascular Medicine and Internal Medicine, Academic Medical Center, University of Amsterdam, Amsterdam, the Netherlands

Corresponding author: Marcel Levi, e-mail: m.m.levi@amc.uva.nl

Published online: 26 September 2005

This article is online at http://ccforum.com/content/9/6/624

(c) 2005 BioMed Central Ltd

Critical Care 2005, 9:624-625 (DOI 10.1186/cc3819)

See related research by Kountchev et al. in this issue [http://ccforum.com/content/9/6/R596]

\begin{abstract}
As the pivotal phase III randomized controlled clinical trial on antithrombin concentrate in patients with severe sepsis did not show a beneficial effect of antithrombin treatment on 28-day mortality, the interest in the potential use of this treatment modality in sepsis has diminished. However, recent data on the effect of antithrombin administration on coagulation in combination with recent analyses from the clinical trials that were aimed to restore physiological anticoagulant pathways in patients with sepsis may revitalize the interest in antithrombin concentrate for the treatment of severe sepsis.
\end{abstract}

\section{Introduction}

Activation of inflammation and coagulation is important in the pathogenesis of sepsis. Natural anticoagulant pathways have a central position at the crossroads of coagulation and inflammation pathways and the restoration of defective anticoagulant pathways in patients with sepsis has, therefore, received considerable attention. In this issue of Critical Care, Kountchev et al. [1] present some observations that may revive interest in the use of antithrombin concentrate in patients with severe sepsis. They show that six hours after the bolus administration of antithrombin, plasma levels of D-dimer, as a marker for the generation of fibrin, was lower in virtually all patients. These data come on top of recent additional analyses on the use of antithrombin concentrate in patients with severe sepsis and may form a new foundation for the further evaluation of this compound in prospective clinical studies.

\section{Antithrombin concentrate in sepsis}

Antithrombin replacement therapy in patients with severe sepsis and disseminated intravascular coagulation (DIC) has been used since the 1980s. The rationale for this adjunctive treatment strategy is based on the notion that natural anticoagulant pathways are defective in patients with a severe systemic inflammatory response upon infection and that this may play a central role in the systemic generation of thrombin and subsequent formation of microthrombi, which may contribute to the pathogenesis of organ dysfunction $[2,3]$. Indeed, plasma levels of antithrombin are (very) low in patients with sepsis and are independent predictors of the clinical outcome [4,5]. A substantial drop in the level of circulating antithrombin has been demonstrated to be a very early phenomenon in sepsis, lending support to the idea that this protease inhibitor is involved in the pathogenesis of the disease. In addition, experimental studies suggest that antithrombin may not only have anticoagulant properties, but also may modulate inflammatory responses [6]. Previous studies have shown that the strong interaction between coagulation and inflammation may indeed be a suitable point of impact for new adjunctive strategies in patients with severe sepsis $[7,8]$. Antithrombin concentrate has been evaluated in several small clinical trials and aggregate results suggest at least a trend towards a reduction in mortality [9]. A large randomized controlled clinical trial in 2,314 patients with severe sepsis (Kybersept trial), however, did not demonstrate a difference between treatment with antithrombin for four days versus placebo [10]. Interestingly, the subgroup of patients that did not receive concomitant heparin (which was at the discretion of the attending physician) had a clear trend towards a better survival at 28 days, which was statistically significant at 90 days. Of note, in the report by Kountchev et al. [1], antithrombin-treated patients that received heparin concomitantly had no improvement of the coagulation derangement. Apparently, the combination of antithrombin concentrate and administration of heparin does not work out very well. Interestingly, this conclusion was already suggested in the very first clinical trials of antithrombin in patients with DIC 25 years ago, but may have been forgotten over time [11]. 


\section{The importance of the anticoagulant effect of antithrombin in sepsis}

The decrease in D-dimer levels after the administration of antithrombin to patients with severe sepsis as observed by Kountchev et al. [1] may be of major significance. It should be remembered that in the phase II dose-finding study of recombinant human activated protein $\mathrm{C}$ in patients with severe sepsis, which preceded the successful placebocontrolled trial showing a survival benefit of this treatment, the dose of activated protein $\mathrm{C}$ was based on the reduction in D-dimer levels [12]. In addition, recent analyses of the Kybersept database reveal that the presence of DIC is a strong predictor of a beneficial effect of antithrombin. In fact, patients that did not receive heparin and that had a positive DIC score (according to the international scoring system [13]) had a relative risk reduction for death of about $30 \%$, whereas patients that did not have DIC had no treatment benefit. This finding is very reminiscent of data from the phase III Prowess trial of recombinant human activated protein $\mathrm{C}$ in patients with severe sepsis showing that patients with DIC had a relatively larger reduction in mortality than patients without DIC [14]. The findings of Koutchev et al. in combination with the subgroup analyses from the Kybersept trial and the experience with recombinant human activated protein $\mathrm{C}$ may indicate that, for selected patients with severe sepsis, administration of antithrombin concentrate may be beneficial. This hypothesis, however, obviously needs prospective confirmation in a properly designed randomized controlled clinical trial. The odds of finding a successful result by administering antithrombin to patients with severe sepsis in such a trial may be greatly improved by the recent insights mentioned above and would evidently have a potentially major impact on the treatment of patients with severe sepsis.

\section{Competing interests}

The author(s) declare that they have no competing interests.

\section{References}

1. Kountchev J, Bijuklic K, Bellmann R, Wiedermann CJ, Joannidis M: Reduction of $\mathrm{D}$-dimer levels after therapeutic administration of antithrombin in acquired antithrombin deficiency of severe sepsis. Crit Care 2005, 9:R596-R600.

2. Esmon CT: Role of coagulation inhibitors in inflammation. Thromb Haemost 2001, 86:51-56.

3. Levi $\mathrm{M}$, de Jonge $\mathrm{E}$, van der Poll $\mathrm{T}$ : Rationale for restoration of physiological anticoagulant pathways in patients with sepsis and disseminated intravascular coagulation. Crit Care Med 2001, 29(Suppl 7):S90-94.

4. Mesters RM, Mannucci PM, Coppola R, Keller T, Ostermann H, Kienast J: Factor VIla and antithrombin III activity during severe sepsis and septic shock in neutropenic patients. Blood 1996, 88:881-886

5. Fourrier F, Chopin C, Goudemand J, Hendrycx S, Caron C, Rime A, Narey P, Lestavel P: Septic shock, multiple organ failure, and disseminated intravascular coagulation. Compared patterns of antithrombin III, protein $\mathrm{C}$, and protein $\mathrm{S}$ deficiencies [see comments]. Chest 1992, 101:816-823.

6. Minnema MC, Chang AC, Jansen PM, Lubbers YT, Pratt BM, Whittaker BG, Taylor FB, Hack CE, Friedman B: Recombinant human antithrombin III improves survival and attenuates inflammatory responses in baboons lethally challenged with Escherichia coli. Blood 2000, 95:1117-1123.
7. Levi M, van der Poll T, Buller HR: Bidirectional relation between inflammation and coagulation. Circulation, 109:2698-2704.

8. Bernard GR, Vincent JL, Laterre PF, LaRosa SP, Dhainaut JF, Lopez-Rodriguez A, Steingrub JS, Garber GE, Helterbrand JD, Ely EW, Fisher CJ Jr; Recombinant human protein C Worldwide Evaluation in Severe Sepsis (PROWESS) study group: Efficacy and safety of recombinant human activated protein $\mathrm{C}$ for severe sepsis. N Engl J Med 2001, 344:699-709.

9. Levi $\mathrm{M}$, ten Cate $\mathrm{H}$, van der Poll $\mathrm{T}$ : Disseminated intravascular coagulation: State of the art. Thromb Haemost 1999, 82:695705.

10. Warren BL, Eid A, Singer P, Pillay SS, Carl P, Novak I, Chalupa P, Penzes I, Kubler A, Knaul S, et al.: Caring for the critically ill patient. High-dose antithrombin III in severe sepsis: a randomized controlled trial. J Am Med Assoc 2001, 286:18691878.

11. Blauhut $B$, Kramar $H$, Vinazzer $H$, Bergmann $H$ : Substitution of antithrombin III in shock and DIC: a randomized study. Thromb Res 1985, 39:81-89.

12. Bernard GR, Ely EW, Wright TJ, Stasek JE, Russell JA, Norris PE, Yau SB, Helterbrand JD: Safety and dose relationship of recombinant human activated protein $\mathrm{C}$ for coagulopathy in severe sepsis. Crit Care Med 2001, 29:2051-2059.

13. Taylor FBJ, Toh CH, Hoots WK, Wada H, Levi M: Towards definition, clinical and laboratory criteria, and a scoring system for disseminated intravascular coagulation. Thromb Haemost 2001, 86:1327-1330.

14. Dhainaut JF, Yan SB, Joyce DE, Petilla V, Busson BR, Brauelt JT, Saudin D, Levi M: Treatment effects of drotrecogin alfa (activated) in patients with severe sepsis with or without overt disseminated intravascular coagulation. J Thromb Haemost 2004, 2:1924-1933. 